\title{
Fungi from Admiralty Bay (King George Island, Antarctica) Soils and Marine Sediments
}

\author{
Lia Costa Pinto Wentzel ${ }^{1}$ • Fábio José Inforsato ${ }^{1}$. Quimi Vidaurre Montoya ${ }^{1} \cdot$ Bruna Gomes Rossin ${ }^{2}$. \\ Nadia Regina Nascimento ${ }^{2}$. André Rodrigues ${ }^{1} \cdot$ Lara Durães Sette $^{1}$ (D)
}

Received: 3 December 2017 / Accepted: 31 May 2018 / Published online: 19 June 2018

(C) Springer Science+Business Media, LLC, part of Springer Nature 2018

\begin{abstract}
Extreme environments such as the Antarctic can lead to the discovery of new microbial taxa, as well as to new microbial-derived natural products. Considering that little is known yet about the diversity and the genetic resources present in these habitats, the main objective of this study was to evaluate the fungal communities from extreme environments collected at Aldmiralty Bay (Antarctica). A total of 891 and 226 isolates was obtained from soil and marine sediment samples, respectively. The most abundant isolates from soil samples were representatives of the genera Leucosporidium, Pseudogymnoascus, and a nonidentified Ascomycota NIA6. Metschnikowia sp. was the most abundant taxon from marine samples, followed by isolates from the genera Penicillium and Pseudogymnoascus. Many of the genera were exclusive in marine sediment or terrestrial samples. However, representatives of eight genera were found in both types of samples. Data from non-metric multidimensional scaling showed that each sampling site is unique in their physical-chemical composition and fungal community. Biotechnological potential in relation to enzymatic production at low/moderate temperatures was also investigated. Ligninolytic enzymes were produced by few isolates from root-associated soil. Among the fungi isolated from marine sediments, 16 yeasts and nine fungi showed lipase activity and three yeasts and six filamentous fungi protease activity. The present study permitted increasing our knowledge on the diversity of fungi that inhabit the Antarctic, finding genera that have never been reported in this environment before and discovering putative new species of fungi.
\end{abstract}

Keywords Extremophiles $\cdot$ Fungal diversity $\cdot$ Marine mycology $\cdot$ Maritime Antarctica $\cdot$ Cold-adapted enzymes

\section{Introduction}

The Antarctic environment is characterized by low temperatures, high UV incidence, dryness, freeze and thaw cycles, low nutrient content, and high salinity, in addition to long periods

Electronic supplementary material The online version of this article (https://doi.org/10.1007/s00248-018-1217-x) contains supplementary material, which is available to authorized users.

\section{Lara Durães Sette}

larasette@rc.unesp.br

1 Instituto de Biociências, Departamento de Bioquímica e Microbiologia, São Paulo State University (UNESP), Av 24A, 1515, Rio Claro 13506-900, SP, Brazil

2 Instituto de Geociências e Ciências Exatas, Departamento de Planejamento Territorial e Geoprocessamento, São Paulo State University (UNESP), Avenida 24A, 1515, Rio Claro 13506-900, SP, Brazil of darkness [1-3]. Despite these extreme conditions, many microorganisms can thrive in this environment. Fungi and bacteria play great ecological roles in the Antarctic environment, but their diversity information is still poorly explored [4]. Fungi that inhabit marine sediments and soil work as decomposers and are dominant components of the biomass in Antarctic ecosystems [5, 6].

Antarctic microorganisms, considered extremophiles, developed adaptation mechanisms, including high concentrations of unsaturated membrane lipids, antifreeze proteins, and enzymes that are active at low temperatures known as cold-adapted enzymes [7-10]. Cold-adapted enzymes are active at low and moderate temperatures, require lower activation energy, and are stable at higher temperatures (the inactivation temperature usually is higher than the catalysis optimal temperature, unlike the mesophilic analogs). All these advantages are attractive for industrial processes because they can decrease energy costs. Besides this, in processes conducted 
with enzymes that are extremely efficient at low temperatures, the contamination by other microorganisms can be avoided $[11,12]$.

Oxidative enzymes can be applied in a wide range of industrial processes in the food and textile industries. Besides, they have pharmaceutical and nanotechnological applications and can also be used for effluent treatment [13-15]. Hydrolytic enzymes such as proteases account for approximately $60 \%$ of the world enzyme trade and are used for treating industrial rejects and in the production of pharmaceuticals $[16,17]$.

Considering the ecological relevance, the potential of fungi to produce oxidases and hydrolases and the properties of coldadapted enzymes, fungi from the Antarctic environment could be considered as interesting microbial resources to be exploited and biotechnologically applied [18]. In this sense, the aim of the present study was to characterize and compare the fungal diversity in marine sediment and in different Antarctic soil samples and also to evaluate the capability of these fungi to produce oxidative (terrestrial fungi) and hydrolytic (marine fungi) enzymes.

\section{Methods}

\section{Sampling Site}

Soil, plants, and marine sediment samples were collected in triplicate at eight different points in the Admiralty Bay region (King George Island, South Shetlands Archipelago, Maritime Antarctica) (Fig. 1) in January 2015. At Yellow Point, two different types of soil (yellow and dark brown soils) were collected $(5 \mathrm{~cm}$ depth). At Punta Hennequin and Punta Plaza, the vascular plants Deschampsia antarctica and Colobanthus quitensis were collected with root-aggregated soil. Marine sediment samples were collected with a Van Veen grab. All samples were stored in sterile plastic bags and kept under refrigeration for up to two months until isolation took place. The triplicates were merged to form composite samples, yielding the final samples listed in Table 1.

\section{Soil and Marine Sediment Physical and Chemical Characterization}

Soil and sediment granulometry was measured by the method adapted from Camargo et al. [19]. To determine iron (Fe) and aluminum $(\mathrm{Al})$ content, three different measurements were done: the dithionite-citrate-bicarbonate procedure as performed by Mehra and Jackson [20], the ammonium oxalate procedure according to McKeague and Day [21], and sodium pyrophosphate after McKeague et al. [22].

\section{Isolation of Soil Microorganisms}

Soil samples (12.5 g) and root-associated soil (6.25 g) were added to Erlenmeyer flasks containing $112.5 \mathrm{~mL}$ of Savitha's minimal medium [23]. As inducers for the production of ligninolytic enzymes, $0.2 \%$ of sterilized sugarcane bagasse and rice straw were added to the samples, separately. The Erlenmeyer flasks were agitated at $140 \mathrm{rpm}$ and incubated at $5{ }^{\circ} \mathrm{C}$ and $15{ }^{\circ} \mathrm{C}$ for 7 days. After the incubation period, $200 \mu \mathrm{l}$ of each sample were taken and serially diluted in a $0.085 \% \mathrm{NaCl}$ solution. The dilutions of $10^{-1}$ and $10^{-3}$ of each sample were plated on Petri dishes. Four different culture media were used (in $\mathrm{g} \mathrm{L}^{-1}$ ): MA2\%: 20 malt extract, 15 agar; MA2\% 10× diluted; BSA: 15 malt extract, 2 yeast extract, 15 agar, 2 lactic acid (added after autoclaving), and B\&K: 10 glucose, 2 peptone, 1 yeast extract, 20 agar, $4 \mathrm{mM}$ guaiacol (added after autoclaving).

\section{Isolation of Marine Sediment Microorganisms}

Isolation was carried out in two steps, with and without sample enrichment. For the enrichment step, $25 \mathrm{~g}$ of each sample were added to Erlenmeyer flasks containing $225 \mathrm{~mL}$ of artificial seawater (ASW) and enzymatic inductors for lipase or protease. Olive oil 1.5\% (v/v) and Tween $801.5 \%(v / v)$ were used as lipase inductors and Skim Milk $2 \%(\mathrm{~m} / \mathrm{v})$ as protease inductor. Each sample was agitated at $150 \mathrm{rpm}$ and incubated at $5{ }^{\circ} \mathrm{C}$ and $15^{\circ} \mathrm{C}$ for 10 days. After this period, $200 \mu \mathrm{L}$ of the dilutions $10^{-1}$ and $10^{-3}$ were inoculated in Petri dishes on four different culture media (in $\mathrm{g} \mathrm{L}^{-1}$ ): PDA: 200 potato, 20 glucose, 15 agar; PDA 10× diluted; BSA, and MA - Marine Agar: 5 peptone, 1 yeast extract, 0.1 ferric citrate, $19.45 \mathrm{NaCl}, 8.8 \mathrm{MgCl}_{2}, 3.24$ $\mathrm{Na}_{2} \mathrm{SO}_{4}, 1.8 \mathrm{CaCl}_{2}, 0.55 \mathrm{KCl}, 0.16 \mathrm{NaHCO}_{3}, 0.08 \mathrm{KBr}$, $34.0 \mathrm{mg} \mathrm{L}^{-1} \mathrm{SrCl}_{2}, 22.0 \mathrm{mg} \mathrm{L}^{-1} \mathrm{HBr}, 4.0 \mathrm{mg} \mathrm{L}^{-1} \mathrm{Na}_{2} \mathrm{SiO}_{3}$, $1.6 \mathrm{mg} \mathrm{L}^{-1} \mathrm{NH}_{4} \mathrm{NO}_{3}, 8.0 \mathrm{mg} \mathrm{L} \mathrm{Na}_{2} \mathrm{HPO}_{4}, 15$ agar. Plates were incubated at 5 and $15^{\circ} \mathrm{C}$. Isolation without the enrichment followed the same principle: $25 \mathrm{~g}$ of each sample in $225 \mathrm{~mL}$ of artificial seawater (ASW), but without any inductor. Each sample was homogenized for $60 \mathrm{~min}$ at $150 \mathrm{rpm}$, at 5 and $15^{\circ} \mathrm{C}$. Then, $200 \mu \mathrm{L}$ of the dilutions $10^{-1}$ and $10^{-3}$ were inoculated in Petri dishes in the same culture media listed above.

For both isolation processes, streptomycin $\left(0.01 \mathrm{~g} \mathrm{~L}^{-1}\right)$ and chloramphenicol $\left(0.1 \mathrm{~g} \mathrm{~L}^{-1}\right)$ were added to all culture media after their autoclavation. Plates were incubated up to 2 months at 5 and $15{ }^{\circ} \mathrm{C}$ to retrieve both psychrophilic and psychrotrophic fungi. Individual colonies of fungi were purified in their isolation media. Long- and medium-term preservation were carried out at -80 and $4{ }^{\circ} \mathrm{C}$ using cryotubes with sterile $10 \%$ glycerol and water, respectively. All of the fungal isolates obtained in this study were deposited in the Microbial Resource Center Culture Collection of the São Paulo State University, Rio Claro, Brazil, under the codes CRM and LAMAI included in the sequences deposited in Genbank (see the topic Accession numbers). 


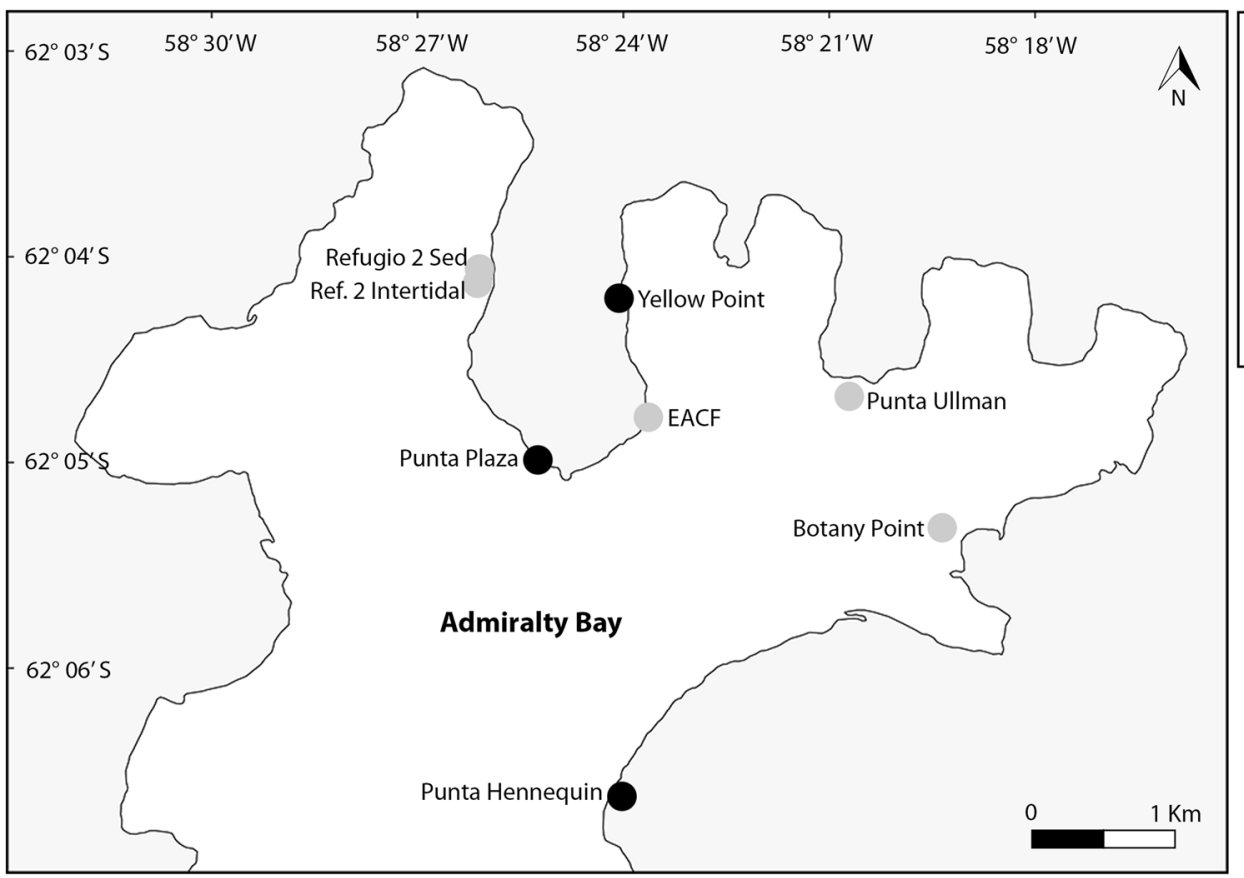

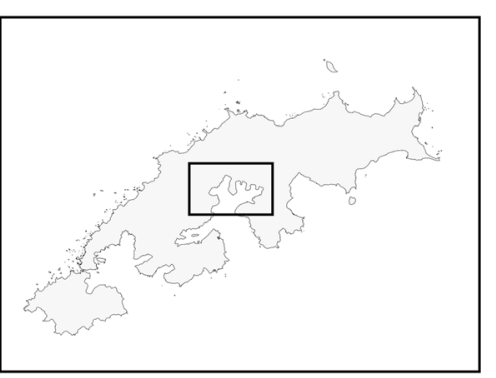

King George Island

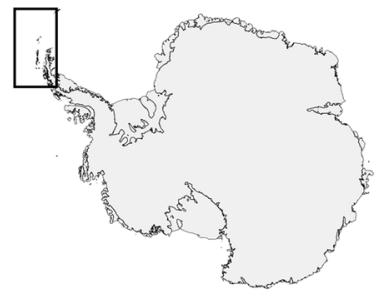

Antarctica

Fig. 1 Sampling sites in Aldmiralty Bay (King George Island, South Shetlands Archipelago, Maritime Antarctica)

\section{Fungal Identification}

Soil filamentous fungi were grouped in morphotypes. Fungal macromorphology was used to separate the morphotypes, and one representative of each morphotype was randomly chosen for DNA sequencing. For marine sediment fungi, all isolates had their DNA sequenced. DNA extraction of the filamentous fungi followed the method of Lacerda et al. [24]. The ITS region was amplified and sequenced with the primer pair ITS4 and ITS5 [25].

A mini satellite-primed PCR (MSP-PCR) was done to separate the soil yeasts in different fingerprints. Yeast DNA
Table 1 Data of the terrestrial and marine samples collected at Admiralty Bay

\begin{tabular}{|c|c|c|c|c|}
\hline Site & Sample & $\begin{array}{l}\text { Geographic } \\
\text { coordenate }\end{array}$ & $\begin{array}{l}\text { Average } T \\
\left({ }^{\circ} \mathrm{C}\right)\end{array}$ & $\begin{array}{l}\text { Average } \\
\text { depth (m) }\end{array}$ \\
\hline Yellow Point (S1) & Yellowish soil & $\begin{array}{c}62^{\circ} 04.479^{\prime} \mathrm{S} ; 58^{\circ} \\
23.726^{\prime} \mathrm{W}\end{array}$ & 3.6 & $\begin{array}{r}\text { Superficial } \\
(5 \mathrm{~cm})\end{array}$ \\
\hline Yellow Point (S2) & Dark brown soil & $\begin{array}{c}62^{\circ} 04.479^{\prime} \mathrm{S} ; 58^{\circ} \\
23.726^{\prime} \mathrm{W}\end{array}$ & 2.5 & $\begin{array}{r}\text { Superficial } \\
(5 \mathrm{~cm})\end{array}$ \\
\hline Punta Hennequin (S3) & $\begin{array}{l}\text { C. quitensis } \\
\text { root-associated soil }\end{array}$ & $\begin{array}{c}62^{\circ} 07.216^{\prime} \mathrm{S} ; 58^{\circ} \\
23.677^{\prime} \mathrm{W}\end{array}$ & 3.6 & $\begin{array}{r}\text { Superficial } \\
(5 \mathrm{~cm})\end{array}$ \\
\hline Punta Hennequin (S4) & $\begin{array}{l}\text { D. antarctica } \\
\text { root-associated soil }\end{array}$ & $\begin{array}{c}62^{\circ} 07.216^{\prime} \mathrm{S} ; 58^{\circ} \\
23.677^{\prime} \mathrm{W}\end{array}$ & 3.5 & $\begin{array}{r}\text { Superficial } \\
(5 \mathrm{~cm})\end{array}$ \\
\hline Punta Plaza (S5) & $\begin{array}{l}\text { D. antarctica } \\
\text { root-associated soil }\end{array}$ & $\begin{array}{c}62^{\circ} 05.363^{\prime} \mathrm{S} ; 58^{\circ} \\
24.691^{\prime} \mathrm{W}\end{array}$ & 6.4 & $\begin{array}{r}\text { Superficial } \\
(5 \mathrm{~cm})\end{array}$ \\
\hline Punta Plaza (S6) & $\begin{array}{l}\text { C. quitensis } \\
\quad \text { root-associated soil }\end{array}$ & $\begin{array}{c}62^{\circ} 05.363^{\prime} \mathrm{S} ; 58^{\circ} \\
24.691^{\prime} \mathrm{W}\end{array}$ & 6.3 & $\begin{array}{r}\text { Superficial } \\
(5 \mathrm{~cm})\end{array}$ \\
\hline Botany Point (Sed1) & Marine sediment & $\begin{array}{c}62^{\circ} 05.734^{\prime} \mathrm{S} 58^{\circ} \\
19.919^{\prime} \mathrm{W}\end{array}$ & 0.6 & 24.7 \\
\hline $\mathrm{EACF}^{\mathrm{a}}(\operatorname{Sed} 2)$ & Marine sediment & $\begin{array}{l}62^{\circ} 05.130^{\prime} \mathrm{S} 58^{\circ} \\
23.356^{\prime} \mathrm{W}\end{array}$ & 0.4 & 22.9 \\
\hline Punta Ullman (Sed3) & Marine sediment & $\begin{array}{c}62^{\circ} 05.015^{\prime} \mathrm{S} 58^{\circ} \\
20.987^{\prime} \mathrm{W}\end{array}$ & 0.3 & 20.3 \\
\hline Refugio 2 (Sed4) & Marine sediment & $\begin{array}{l}62^{\circ} 04.373^{\prime} \mathrm{S} 58^{\circ} \\
25.335^{\prime} \mathrm{W}\end{array}$ & 0.1 & 20.0 \\
\hline $\begin{array}{l}\text { Refugio } 2 \text { intertidal } \\
\text { zone (Sed5) }\end{array}$ & Marine sediment & $\begin{array}{c}62^{\circ} 04.341^{\prime} \mathrm{S} 58^{\circ} \\
25.233^{\prime} \mathrm{W}\end{array}$ & 2.4 & $\begin{array}{r}\text { Superficial } \\
(5 \mathrm{~cm})\end{array}$ \\
\hline
\end{tabular}

${ }^{\mathrm{a}} \mathrm{EACF}$ in front of the Brazillian Station 
extraction followed the method adapted from Sampaio et al. [26] and De Almeida [27]. MSP-PCR was performed using $(\mathrm{GTG})_{5}$ primer according to Duarte et al. [28]. One representative of each different fingerprint was randomly selected for DNA sequencing. The LSU (D1/D2) region was amplified and sequenced with the primer pair NL1 and NL4 [29]. PCR for LSU was performed according to Duarte et al. [28].

Amplicons from filamentous fungi and yeasts were purified using the enzymes Exonuclease I and Alkaline phosphatase (Thermo Scientific, Massachusetts, USA) according to the manufacturer's protocol. Samples were quantified in NanoDrop ${ }^{\circledR}$ (Thermo Scientific) and sequenced using the BigDye Terminator ${ }^{\circledR}$ v.3.1 kit (Applied Biosystems, California, USA) after the manufacturer's instructions in an ABI 3500 sequencer (Applied Biosystems). The sequencing conditions for all molecular markers were $95^{\circ} \mathrm{C} / \mathrm{min}$ followed by 28 cycles at $95^{\circ} \mathrm{C} / 15 \mathrm{~s}, 50{ }^{\circ} \mathrm{C} / 45 \mathrm{~s}$, and $60^{\circ} \mathrm{C} / 4 \mathrm{~min}$. The generated sequences were assembled into contigs in BioEdit v.7.2.5 [30] and compared to homologous sequences deposited in the NCBI-GenBank database using BLAST. Data sets comprising the assembled sequences (those generated in this study and the sequences obtained from the database) were aligned in MAFFT v 7 [31]. The alignments were prepared separately for each fungus genus. Phylogenetic trees were inferred in MEGA v.7.1 [32], using the Neighbor-joining method and with Kimura 2-parameters nucleotide substitution model [33]. The robustness of the trees was calculated using the bootstrap method, with 1000 generations.

\section{Accession Numbers}

Sequences generated in this study were deposited in Genbank under accession numbers MG735773-MG736057 (yeasts) and MH128164-MH128317 (filamentous fungi).

\section{Soil/Marine Sediment-Taxonomy Correlation, Species Diversity, Richness, and Distribution}

Soil and marine sediment physical-chemical characteristics were related to the species composition profile of each sample by non-metric multidimensional scaling (NMDS). An analysis of similarities (ANOSIM) using a Bray-Curtis dissimilarity matrix was performed to verify if there were differences between soil sample groups $(C$. quitensis rootassociated soil and D. antarctica root-associated soil) and between the two isolation temperatures. All analyses were performed using PAST v. 2.17c [34]. To quantify species diversity, the Shannon and the inverse Simpson indices were calculated and for species richness, the Chao-1 estimator was used. The similarities among fungal taxa from different samples were estimated using the Bray-Curtis, Sorensen, and Jaccard indices. All indices and estimators were calculated in EstimateS v.9.1.0 [35].

\section{Screening of Cold-Adapted Enzymes}

Soil isolates were screened for ligninolytic enzymes laccase, manganese peroxidase, and lignin peroxidase. The first screening was done on $\mathrm{B} \& \mathrm{~K}$ medium with guaiacol $4 \mathrm{mM}$ (during the isolation step) according to Verma et al. [36]. The presence of an intense brown color under the mycelium and surrounding it indicated the probable presence of laccase activity. Isolates that showed this characteristic were selected for the quantitative tests. Marine sediment isolates were screened for lipase and protease. Screening for lipase was done according to Kouker and Jaeger [37], with modification on Tubaki medium (in $\mathrm{g}$ $\mathrm{L}^{-1}$ ): 1 peptone, 0.5 yeast extract, $15 \mathrm{agar}, 31.25 \mathrm{~mL}$ of olive oil and Rhodamine B solution $0.01 \%(v / v)$. Lipase production was detected by the presence of a degradation halo around the colonies. For protease screening, the fungi were inoculated on skim milk medium (in $\mathrm{g} \mathrm{L}^{-1}$ ): 20 skim milk, 20 agar, and $0.2 \mathrm{M}$ $\mathrm{pH} 7$ phosphate buffer. The presence of a clear degradation halo around the colonies indicated protease production.

\section{Cold-Adapted Enzymes Activity Quantification}

Soil fungi screened positive for ligninolytic enzymes were cultivated in MA2\% medium. After their growth, two 5-mm cylinders from the margin of the isolates' colonies were transferred to $150-\mathrm{mL}$ flasks containing $50 \mathrm{~mL}$ of malt broth $2 \%$. Assays were incubated at $15{ }^{\circ} \mathrm{C}$ for 7 days at $150 \mathrm{rpm}$ in duplicates. After this step, the liquid media were centrifuged at $10,000 \mathrm{rpm}$ for $30 \mathrm{~min}$ at $4{ }^{\circ} \mathrm{C}$. Enzymatic activity was measured in triplicate using the broth obtained. Quantification of lignin peroxidase followed the method adapted from Arora and Gill [38]. Manganese peroxidase was quantified following the method from Wariishi et al. [39], and the determination of laccase activity was measured by the method reported by Buswell et al. [40]. Lipase quantification was determined following the method reported by Yang et al. [41]. The protease activity was determined as described by Charney and Tomarelli [42]. For ligninolytic enzymes, one enzymatic unit (U) was defined as the amount of enzyme needed to oxidize $1 \mu \mathrm{mol}$ of substrate per minute. One unit of lipase activity (U) was defined as the amount of enzyme capable of releasing $1 \mu \mathrm{mol}$ of $\mathrm{p}-\mathrm{NPP}$ per $\mathrm{mL}$ per min of reaction. One unit of protease (U) was defined as the amount of enzyme required to increase the absorbance by 0.01 under the conditions used.

\section{Results}

\section{Fungi from Soil Samples}

A total of 891 isolates was obtained comprehending 399 yeasts and 492 filamentous fungi. The yeasts were recovered 
on MA2\% $(n=117), \mathrm{B} \& \mathrm{~K}(n=107), \mathrm{BSA}(n=96)$, and diluted MA2 $\%(n=79)$. For filamentous fungi, BSA $(n=$ $172)$, B\&K $(n=142)$, MA2 $\%(n=90)$, and diluted MA2\% $(n=88)$. From the two soil samples, 141 isolates were recovered and from the four root-associated soil samples, 750 . The temperature of $15^{\circ} \mathrm{C}$ resulted in a higher number of isolates $(58.5 \%)$, whereas $41.5 \%$ were recovered at $5{ }^{\circ} \mathrm{C}$. The ANOSIM for the temperatures confirmed that there was a significant difference between both employed temperatures $(R=0.479 ; p=0.002)$.

The morphotyping step resulted in 66 morphotypes at $15{ }^{\circ} \mathrm{C}$, and 85 morphotypes at $5{ }^{\circ} \mathrm{C}$. For the yeasts, 114 different fingerprints were obtained. Thus, from the total 891 fungal isolates, 667 were sequenced. They were identified in 35 different taxa within the phyla Ascomycota, Basidiomycota, and Mucoromycota (Table 2). Most of the filamentous fungi belonged to the Ascomycota, and most of the yeasts belonged to the Basidiomycota. Six fungal taxa (Ascomycota) presented low molecular similarities in comparison to sequences in the NCBI-GenBank database. Even after phylogenetic trees were built, their identification remained inconclusive and therefore they were classified as NIA (non-identified ascomycetes; their phylogenetic trees are available in the Supplementary Material, Figs. S1-S5). Among the yeasts, the most represented taxa were Leucosporidium sp. (44.4\%), the NIA6 (21.4\%), Goffeauzyma sp. (11.2\%), and Holtermanniella sp. $(10.8 \%)$. Among the filamentous fungi, Pseudogymnoascus was the dominant taxon (31.7\%) after NIA2 (5.1\%) and Mortierella sp. 1 (4.5\%). In contrast, the taxa Vishniacozyma sp., Cadophora sp., Cosmospora sp.3, Laetinaevia sp., Thelebolus sp., Mortierella sp.2, and NIA3 were the least dominant, with an abundance of $\leq 1.2 \%$ (Table 2). The most dominant genera, Leucosporidium and Pseudogymnoascus, were also dominant in all types of samples. Mortierella sp.2 was found exclusively in the soil sample S2. Cadophora sp., Oidiodendron sp., and Thelebolus sp. occurred exclusively in the D. antarctica root-associated soil sample S5. On the other hand, Cosmospora sp.3, Laetinaevia sp., and Purpureocillium sp. occurred exclusively in the $C$. quitensis rootassociated soil sample S6. There were no species that occurred exclusively according to the plant species $(C$. quitensis or $D$. antarctica). Some taxa were isolated only at $5{ }^{\circ} \mathrm{C}$, such as NIA3, NIA5, Cadophora sp., and Thelebolus sp. By contrast, the taxa NIA1, NIA2, Cosmospora sp.2 and Cosmospora sp.3, Laetinaevia sp., Penicillium sp., Pochonia sp., Purpureocillium sp., Trichoderma sp., and Mortierella sp. 2 were isolated only at $15{ }^{\circ} \mathrm{C}$. According to Table 2, 22.9\% of total identified isolates were recovered from sample $\mathrm{S} 6,21.4 \%$ from sample S5, $19 \%$ from sample S4, $18.4 \%$ from sample S3, $10.8 \%$ from sample S2, and $7.3 \%$ from sample S1.
Table 2 Fungal taxa from soil samples

\begin{tabular}{|c|c|c|c|c|c|c|c|}
\hline Taxon & $\mathrm{S} 1$ & S2 & S3 & $\mathrm{S} 4$ & S5 & S6 & Total \\
\hline \multicolumn{8}{|l|}{ Ascomycota } \\
\hline ANI1 & 0 & 2 & 3 & 0 & 2 & 1 & 8 \\
\hline ANI2 & 0 & 0 & 4 & 4 & 6 & 11 & 25 \\
\hline ANI3 & 0 & 0 & 1 & 0 & 0 & 0 & 1 \\
\hline ANI4 & 0 & 0 & 2 & 2 & 4 & 3 & 11 \\
\hline ANI5 & 0 & 0 & 2 & 0 & 1 & 1 & 4 \\
\hline ANI6 & 3 & 2 & 12 & 23 & 18 & 11 & 69 \\
\hline Antarctomyces sp. & 1 & 0 & 11 & 2 & 2 & 3 & 19 \\
\hline Cadophora sp. & 0 & 0 & 0 & 0 & 1 & 0 & 1 \\
\hline Cladosporium sp. & 0 & 1 & 0 & 0 & 6 & 1 & 8 \\
\hline Cosmospora sp1 & 0 & 0 & 1 & 1 & 1 & 6 & 9 \\
\hline Cosmospora sp2 & 0 & 0 & 0 & 0 & 3 & 5 & 8 \\
\hline Cosmospora sp3 & 0 & 0 & 0 & 0 & 0 & 1 & 1 \\
\hline Fusarium sp. & 0 & 0 & 1 & 2 & 10 & 5 & 18 \\
\hline Laetinaevia sp. & 0 & 0 & 0 & 0 & 0 & 1 & 1 \\
\hline Leptosphaeria sp. & 0 & 1 & 0 & 1 & 0 & 12 & 14 \\
\hline Microdochium sp. & 0 & 0 & 1 & 6 & 1 & 3 & 11 \\
\hline Oidiodendron sp. & 0 & 0 & 0 & 0 & 2 & 0 & 2 \\
\hline Penicillium sp. & 1 & 0 & 2 & 1 & 1 & 0 & 5 \\
\hline Pochonia sp. & 0 & 0 & 0 & 0 & 1 & 1 & 2 \\
\hline Pseudogymnoascus sp1 & 4 & 9 & 25 & 7 & 15 & 6 & 66 \\
\hline Pseudogymnoascus sp2 & 0 & 0 & 1 & 4 & 2 & 3 & 10 \\
\hline Pseudogymnoascus sp3 & 1 & 13 & 17 & 19 & 13 & 17 & 80 \\
\hline Purpureocillium sp. & 0 & 0 & 0 & 0 & 0 & 3 & 3 \\
\hline Thelebolus sp. & 0 & 0 & 0 & 0 & 1 & 0 & 1 \\
\hline Trichoderma sp. & 0 & 0 & 0 & 0 & 7 & 3 & 10 \\
\hline Varicosporium sp. & 0 & 0 & 2 & 2 & 0 & 0 & 4 \\
\hline \multicolumn{8}{|l|}{ Basidiomycota } \\
\hline Cystobasidium sp. & 0 & 0 & 3 & 0 & 3 & 4 & 10 \\
\hline Goffeauzyma sp. & 1 & 4 & 6 & 21 & 1 & 3 & 36 \\
\hline Holtermanniella sp. & 1 & 5 & 5 & 5 & 12 & 7 & 35 \\
\hline Leucosporidium sp. & 29 & 23 & 20 & 23 & 17 & 31 & 143 \\
\hline Mrakia sp. & 0 & 0 & 2 & 3 & 2 & 6 & 13 \\
\hline Naganishia sp. & 7 & 4 & 1 & 1 & 0 & 1 & 14 \\
\hline Vishniacozyma sp. & 0 & 0 & 1 & 0 & 1 & 0 & 2 \\
\hline \multicolumn{8}{|l|}{ Mucoromycota } \\
\hline Mortierella sp.1 & 1 & 7 & 0 & 0 & 10 & 4 & 22 \\
\hline Mortierella sp.2 & 0 & 1 & 0 & 0 & 0 & 0 & 1 \\
\hline Total & 49 & 72 & 123 & 127 & 143 & 153 & 667 \\
\hline
\end{tabular}

S1 Yellow Point (yellowish soil), S2 Yellow Point (dark brown soil), S3 Punta Hennequin (C. quitensis root-associated soil), S4 Punta Hennequin (D. antarctica root-associated soil), S5 Punta Plaza (D. antarctica rootassociated soil), S6 Punta Plaza (C. quitensis root-associated soil)

\section{Fungi from Marine Sediment Samples}

A total of 226 isolates was obtained. In the first phase (with enrichment), 146 yeasts and 24 filamentous fungi were recovered from the five samples. The yeast isolates were recovered 
with PDA $(n=52)$, diluted PDA $(n=49)$, BSA $(n=23)$, and MA $(n=22)$. For filamentous fungi, PDA $(n=12)$, PDA diluted $(n=4)$, BSA $(n=8)$, and no fungi were isolated from MA medium. From the second isolation phase (without enrichment), 56 isolates were recovered. A total of 20 yeasts was recovered from the four media: PDA $(n=5)$, PDA diluted $(n=8)$, MA $(n=7)$, and no isolate from BSA. Thirty-six filamentous fungi were recovered: PDA $(n=4)$, PDA diluted $(n=5)$, BSA $(n=8)$, and MA $(n=19)$. From the total of isolates, $68 \%$ were isolated at $15{ }^{\circ} \mathrm{C}$. The ANOSIM for the temperatures confirmed that there was a significant difference between both employed temperatures $(R=0.33 ; p=0.03)$.

According to sequencing data and phylogenetic analyses, representatives of nine yeast genera were recovered from the sediment samples (Table 3). The genus Metschnikowia was the most abundant $(45.1 \%)$, followed by isolates from the genera Mrakia (21.6\%), Cryptococcus and Glaciozyma (7.8\%), Meyerozyma and Holtermanniella (5.4\%), Rhodotorula (4.2\%), Cystobasidium (1.8\%), and Phenoliferia $(0.6 \%)$. For filamentous fungi, representatives of eight genera were isolated from the marine sediment samples (Table 3). The genera Penicillium and Pseudogymnoascus were the most abundant (40.0\%), followed by the genera Cadophora (6.6\%), Cladosporium (5.0\%), Toxicocladosporium, Pseudocercosporella, Pestalotiopsis, and Paraconiothyrium (1.6\%). Some of the fungi identified in the present study have never been reported in Antarctic environments before (Toxicocladosporium, Pseudocercosporella, and Paraconiothyrium) and one isolate was not identified. According to Table 3, 35.8\% of total isolates were recovered from sample Sed5, $24.7 \%$ from sample Sed4, $17.2 \%$ from sample Sed3, $11.5 \%$ from sample Sed1, and $10.6 \%$ from sample Sed2.

Although different culture conditions were applied to isolate fungi from terrestrial and marine samples, they shared the taxa Pseudogymnoascus, Penicillium, Cladosporium, Cadophora, Mrakia, Goffeauzyma, Cystobasidium, and Holtermanniella (Fig. 2).

\section{Soil-Taxonomy Correlation, Species Diversity, Richness, and Distribution}

The NMDS analysis (Fig. 3a) revealed that the samples were separated by sampling location by coordinate 1 (samples S3 and S4 - Punta Hennequin, samples S5 and S6 - Punta Plaza). Samples S1 and S2, despite collected at the same place, they presented distinct physical and chemical characteristics, except for the carbon content, and appear distant from each other on the graph (Fig. 3a). The $\mathrm{pH}$ and the $\mathrm{Fe}$ and $\mathrm{Al}$ amounts are the characteristics that contribute to this distance. Data from soil physical and chemical characterizations are available in the Supplementary Information (Tables S1 and S2). The main factors that grouped samples S5 and S6 were the carbon
Table 3 Fungal taxa from sediment samples

\begin{tabular}{|c|c|c|c|c|c|c|}
\hline Taxon & Sed 1 & Sed2 & Sed3 & Sed4 & Sed5 & Total \\
\hline \multicolumn{7}{|l|}{ Ascomycota } \\
\hline Pseudogymnoascus sp.1 & 1 & 0 & 1 & 0 & 4 & 6 \\
\hline Pseudogymnoascus sp.2 & 0 & 0 & 0 & 1 & 0 & 1 \\
\hline Pseudogymnoascus sp.3 & 6 & 2 & 2 & 1 & 4 & 15 \\
\hline Pseudogymnoascus sp.4 & 0 & 0 & 0 & 2 & 0 & 2 \\
\hline Penicillium sp. & 5 & 3 & 9 & 5 & 2 & 24 \\
\hline Cladosporium sp.1 & 0 & 1 & 0 & 0 & 0 & 1 \\
\hline Cladosporium sp.2 & 0 & 0 & 1 & 0 & 0 & 1 \\
\hline Cladosporium sp.3 & 0 & 0 & 1 & 0 & 0 & 1 \\
\hline Pestalotiopsis sp. & 0 & 0 & 0 & 0 & 1 & 1 \\
\hline Pseudocercosporella sp. & 0 & 0 & 0 & 1 & 0 & 1 \\
\hline Paraconiothyrium sp. & 0 & 0 & 0 & 1 & 0 & 1 \\
\hline Toxicocladosporium sp. & 0 & 0 & 0 & 1 & 0 & 1 \\
\hline Cadophora sp. & 0 & 4 & 0 & 0 & 0 & 4 \\
\hline Metschnikowia sp. & 1 & 6 & 2 & 22 & 44 & 75 \\
\hline Meyerozyma sp. & 7 & 0 & 1 & 0 & 1 & 9 \\
\hline Non identified & 0 & 0 & 1 & 0 & 0 & 1 \\
\hline \multicolumn{7}{|l|}{ Basidiomycota } \\
\hline Rhodotorula sp. & 0 & 0 & 0 & 1 & 6 & 7 \\
\hline Mrakia sp. & 3 & 6 & 10 & 16 & 1 & 36 \\
\hline Cryptococcus sp. & 0 & 0 & 11 & 1 & 1 & 13 \\
\hline Glaciozyma sp.1 & 0 & 2 & 0 & 1 & 3 & 6 \\
\hline Glaciozyma sp.2 & 1 & 0 & 0 & 0 & 0 & 1 \\
\hline Glaciozyma sp. 3 & 2 & 0 & 0 & 0 & 4 & 6 \\
\hline Cystobasidium sp. & 0 & 0 & 0 & 3 & 0 & 3 \\
\hline Holtermanniella sp. & 0 & 0 & 0 & 0 & 9 & 9 \\
\hline Phenoliferia sp. & 0 & 0 & 0 & 0 & 1 & 1 \\
\hline Total & 26 & 24 & 39 & 56 & 81 & 226 \\
\hline
\end{tabular}

Sed1 Botany Point, Sed2 EACF, Sed3 Punta Ullman, Sed4 Refúgio 2 (Sediment), Sed5 Refugio 2 (intertidal zone)

content and the amounts of $\mathrm{Fe}$ and $\mathrm{Al}$ (Piro). There was no separation of samples by type (e.g., samples $\mathrm{S} 3$ and $\mathrm{S} 6, C$. quitensis root-associated soil, did not form a group) but by sampling location. The ANOSIM for the groups of samples $C$. quitensis root-associated soil and D. antarctica rootassociated soil showed that there was no significant difference between the two groups $(R=-1 ; p=1)$. This means that the type of plant is not significant for the composition of the fungal communities.

The indices and richness estimator are listed in Table 4. Estimator Chao 1 showed that sample S6 has the major estimated richness. Shannon and Inverse Simpson indices were higher in samples S5 and S6. Species sharing analysis showed that the highest similarity occurred between samples $\mathrm{S} 3$ and S4 (68\%) followed by samples S3 and S5 (63.9\%) and S5 and S6 $(63.5 \%)$. Samples that shared the least species were samples S1 and S5, with $31.3 \%$ of shared species, and samples S1 and $\mathrm{S} 3$, with $38.4 \%$ of species similarity. 
Fig. 2 Diagram showing the genera isolated from each type of sample

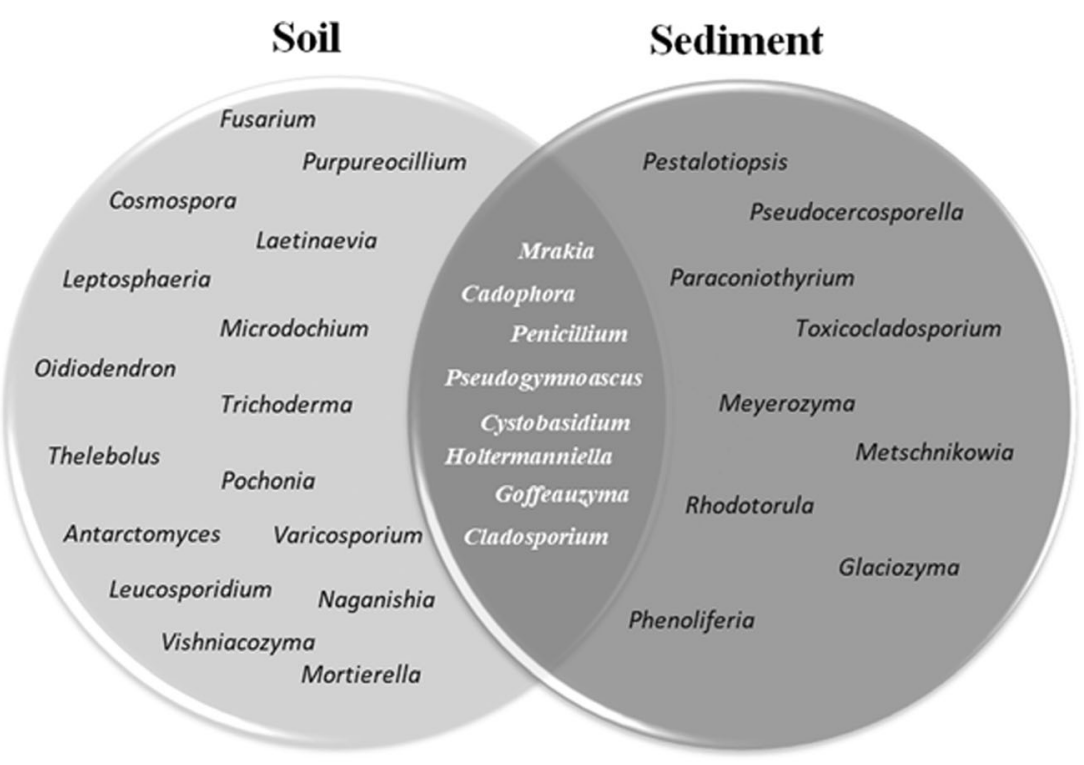

\section{Marine Sediment-Taxonomy Correlation, Species Diversity, Richness, and Distribution}

The NMDS analysis revealed that samples do not form a cohesive group since each sample is in a different place in the graph (Fig. 3b). All samples were collected at different places in Antarctica and showed unique characteristics. Data from sediment physical and chemical characterizations are available in the Supplementary Information (Tables S1 and S2). Samples Sed1, Sed2, and Sed3 are separated from Sed4 and Sed5. Besides this, coordinate 2 separated samples Sed3 and Sed 4 from the others. Estimator Chao 1 showed that sample Sed4 has the highest estimated richness (Table 5); this sample has more rare species (singletons and doubletons) than the others. Shannon index was higher in sample Sed1, while Inverse Simpson was higher in sample Sed2 (Table 5). Species sharing ( $\beta$-Diversity) showed that the major similarity occurred between samples Sed4 and Sed5 (42.3\%), followed by samples Sed3 and Sed4 (40.0\%). The least similarity occurred between samples Sed3 and Sed5 (only 15\%).

\section{Screening of Cold-Adapted Enzymes and Activity Quantification}

From the 249 soil isolates grown on $\mathrm{B} \& \mathrm{~K}, 35$ showed probable laccase activity. Only one was from a soil sample, the others were from root-associated soil samples. Two isolates were recovered at $5{ }^{\circ} \mathrm{C}$ and the rest at $15{ }^{\circ} \mathrm{C}$. Three isolates showed enzymatic activity higher than or equal to $1 \mathrm{U} \mathrm{L}^{-1}$ for lignin peroxidase: isolate 9P-1.9 $\left(5.41 \mathrm{U} \mathrm{L}^{-1}\right)$, isolate 12P3.10B $\left(1.7 \mathrm{U} \mathrm{L}^{-1}\right)$, and 9P-3.19 $\left(1 \mathrm{U} \mathrm{L}^{-1}\right)$. There was no detectable activity for manganese peroxidase and values for laccase were under $0.2 \mathrm{U} \mathrm{L}^{-1}$. The 170 isolates (marine sediment) from the first isolation phase were tested for lipase production. In the qualitative step, 60 yeasts and 19 fungi showed a positive result. After this, the positive ones were tested in quantification phase, and 16 yeasts and nine fungi showed measurable lipase activity. Nevertheless, only nine yeast isolates were able to produce lipase above $0.5 \mathrm{U} \mathrm{mL}^{-1}$. The best result $\left(0.88 \mathrm{U} \mathrm{mL}^{-1}\right)$ was achieved by Metschnikowia sp. CRM1589. After the experimental design, this isolate increased its lipase production to $1.05 \mathrm{U} \mathrm{mL}^{-1}$ (data not shown). All the isolates from marine sediment were also tested for protease production. In the qualitative step, three yeasts and six filamentous fungi showed a positive result. After this, the positive isolates were tested in quantification phase, and all of them showed measurable protease activity. In this case, six filamentous fungi were able to produce protease above $2.0 \mathrm{U} \mathrm{mL}^{-1}$. The best result $\left(6.21 \mathrm{U} \mathrm{mL}^{-1}\right)$ was from Pseudogymnoascus sp. CRM1533. After the experimental design, the isolate Pseudogymnoascus sp. CRM1533 increased its protease production to $11.47 \mathrm{U} \mathrm{mL}^{-1}$ (data not shown).

\section{Discussion}

\section{Fungal Isolation and Identification}

The number of isolates and the different genera identified in this study revealed that yeasts and filamentous fungi could be recovered from extreme-condition samples of the Antarctic terrestrial and marine environments. As expected, there were more isolates retrieved from soil samples than from marine sediment, and more from root-associated soil than from bulk soil. As the roots release organic carbon, it is reasonable to believe that more isolates can be found in this environment [43]. Moreover, according to Berríos et al. [44], 
Fig. 3 Two non-metric multidimensional scaling (NMDS) biplots based on Bray-Curtis distances displaying the total fungal community distribution. a Soil samples and $\mathbf{b}$ marine sediment samples
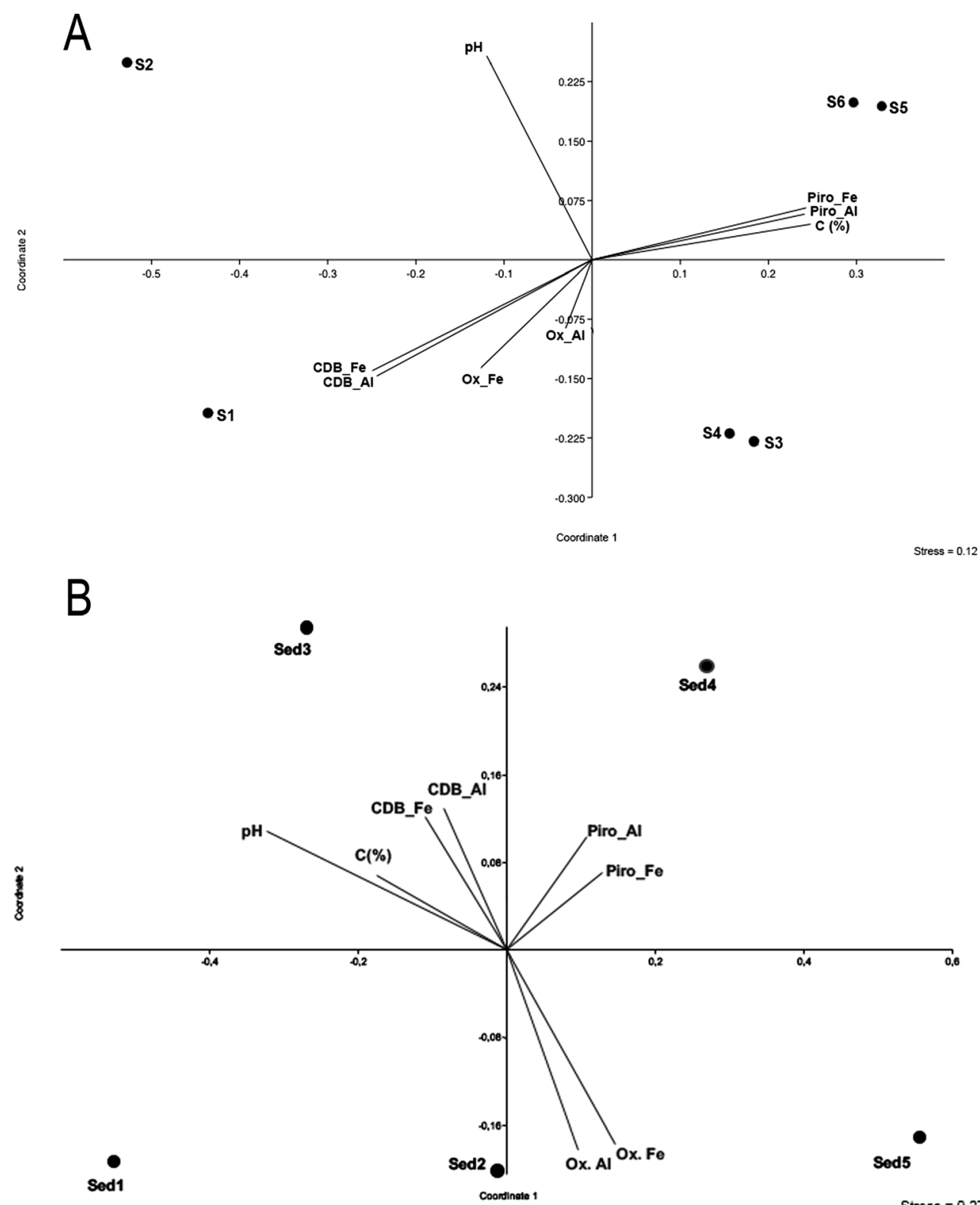

some microorganisms from the rhizosphere of $D$. antarctica can have a significant role in the survival and adaptation of this plant in maritime Antarctica.

Ascomycota is the most common fungal phylum found in Antarctica [45]. In our study, we also had most of the filamentous fungi as representatives of this phylum. On the other hand, most of the yeasts were Basidiomycota. Metschnikowia was the most abundant yeast genus found in marine sediment samples, while Leucosporidium was the most abundant in soil samples. Representatives of the genus Metschnikowia are very common in Antarctica and also reported from water, ice, algae, sediments, and soil [28, 46-48]. On the other hand, Leucosporidium is widespread in alpine and polar environments [49] and was isolated from different substrates. The genera Penicillium and Pseudogymnoascus were the most abundant in marine sediments. In the soil samples, the most abundant ones were Mortierella and Pseudogymnoascus. According to Hayes [50], species from the genus Pseudogymnoascus are distributed globally and are common in cold environments. Moreover, Arenz et al. [51] suggest that this genus takes part in the decomposition and nutrient cycling in Antarctica. The genera Penicillium and Pseudogymnoascus are spread worldwide, and several species can develop in different and extreme conditions [50, 52].

An interesting result is the presence of Toxicocladosporium, Pseudocercosporella, and Paraconiothyrium in marine sediment samples. These genera have not been reported in the Antarctic environment yet. Toxicocladosporium is related to Cladosporium but now is recognized as a different genus [53]. The isolates in this study showed high sequence 
Table 4 Indices and richness estimator ( $\alpha$ and $\beta$-diversity) for soil samples

\begin{tabular}{lllll}
\hline Sample & Shannon & Simpson Inv. & Chao1 & S \\
S1 (Soil1) & 1.44 & 2.61 & 24.69 & 10 \\
S2 (Soil2) & 2.04 & 5.79 & 12.99 & 12 \\
S3 (Soil3) & 2.51 & 8.89 & 25.47 & 22 \\
S4 (Soil4) & 2.35 & 7.94 & 19.19 & 18 \\
S5 (Soil5) & 2.84 & 13.32 & 32.96 & 27 \\
S6 (Soil6) & 2.8 & 11.51 & 46.86 & 26 \\
First sample & Second sample & Jaccard & Sorensen & Bray-Curtis \\
S1 & S2 & 0.571 & 0.727 & 0.612 \\
S1 & S3 & 0.391 & 0.563 & 0.384 \\
S1 & S4 & 0.474 & 0.643 & 0.409 \\
S1 & S5 & 0.321 & 0.486 & 0.313 \\
S1 & S6 & 0.321 & 0.486 & 0.416 \\
S2 & S3 & 0.308 & 0.471 & 0.574 \\
S2 & S4 & 0.364 & 0.533 & 0.563 \\
S2 & S5 & 0.3 & 0.462 & 0.53 \\
S2 & S6 & 0.393 & 0.564 & 0.533 \\
S3 & S4 & 0.739 & 0.85 & 0.68 \\
S3 & S5 & 0.633 & 0.776 & 0.639 \\
S3 & S6 & 0.581 & 0.735 & 0.601 \\
S4 & S5 & 0.5 & 0.667 & 0.578 \\
S4 & S6 & 0.552 & 0.711 & 0.621 \\
S5 & S6 & 0.688 & 0.815 & 0.635 \\
\hline
\end{tabular}

similarity with Toxicocladosporium strelitziae; however, the phylogenetic tree did not confirm this identification. This genus is commonly associated with plants, and a large number of species are phytopathogens. Also, some species were

Table 5 Indices and richness estimator ( $\alpha$ and $\beta$-diversity) for sediment samples

\begin{tabular}{lllll}
\hline Sample & Shannon & Simpson Inv. & Chao1 & S \\
Sed1 & 1.83 & 5.37 & 9.44 & 8 \\
Sed2 & 1.8 & 5.43 & 7 & 7 \\
Sed3 & 1.82 & 4.83 & 13.25 & 10 \\
Sed4 & 1.79 & 3.99 & 26.75 & 13 \\
Sed5 & 1.73 & 3.11 & 21.41 & 14 \\
First sample & Second sample & Jaccard & Sorensen & Bray-Curtis \\
Sed1 & Sed2 & 0.364 & 0.533 & 0.36 \\
Sed1 & Sed3 & 0.5 & 0.667 & 0.4 \\
Sed1 & Sed4 & 0.313 & 0.476 & 0.268 \\
Sed1 & Sed5 & 0.467 & 0.636 & 0.206 \\
Sed2 & Sed3 & 0.308 & 0.471 & 0.413 \\
Sed2 & Sed4 & 0.25 & 0.4 & 0.4 \\
Sed2 & Sed5 & 0.313 & 0.476 & 0.248 \\
Sed3 & Sed4 & 0.278 & 0.435 & 0.4 \\
Sed3 & Sed5 & 0.333 & 0.5 & 0.15 \\
Sed4 & Sed5 & 0.35 & 0.519 & 0.423 \\
\hline
\end{tabular}

recovered from clinic samples [53-57]. The genus Pseudocercosporella has several species that are associated with plants and also as phytopathogens [58]. The isolates showed 99\% identity similarity with Pseudocercosporella fraxini, but the phylogenetic tree did not confirm this data. Most species of the genus Paraconiothyrium are usually associated with plants. This genus has been previously found in marine sponges and sea sediments [59-63].

\section{Putative New Species}

Among the total soil fungi recovered, six taxa were not identified at the genus level and were therefore labeled as "non-identified ascomycete" (NIA); NIA1 showed close relatedness to the only two described species for the genus Rhizoscyphus, which are commonly associated with the roots of $C$. quitensis and $D$. Antarctica [64]. The non-identified ascomycetes 2 and 3 had low bootstrap values in the phylogenetic tree, and therefore their identification remained inconclusive. NIA5 showed $93 \%$ similarity with Urceolella carestiana; in the phylogenetic tree, the isolate was placed very distantly from that species and could represent a new genus. Isolates identified as Oidiodendron sp. could also represent new species to science (for the phylogenetic tree, see Supplementary Material, Fig. S6). Among the marine isolates obtained in this study, one taxon was not identified due to its low similarity to other sequences in Genbank (for the phylogenetic tree, see Supplementary Material, Fig. S7). The best match was with Phaeoacremonium santali, but the similarity was only $86 \%$.

\section{Soil Diversity}

There are few studies addressing fungi in root-associated soil in the two vascular plants that inhabit Antarctica. Vaz et al. [10] reported 12 different yeast taxa from the rhizosphere of D. antarctica. Gonçalves et al. [65] obtained nine different genera of filamentous fungi from the rhizosphere of $D$. antarctica. Microbial communities in root-associated soils are shaped by the plant species, and consequently by the type of exudates that they release $[66,67]$. Thus, it was expected that $C$. quitensis and $D$. antarctica would present some influence on the fungal communities on their root-associated soils. Conversely, it was observed that the structure of the community was similar for samples collected in the same place, regardless of the plant species, and more related to the characteristics of the soil. Although there was no significant difference between the microbial composition found in rootassociated soils of $C$. quitensis and $D$. antarctica, the fungal communities varied in the presence of plants among the sampling sites. The $\alpha$-diversity analyses showed that samples S5 and S6 (C. quitensis and D. antarctica root-associated soil Punta Plaza) were the richest and most diverse ones. The $\beta$ diversity results were expected since samples collected at the 
same sampling point showed high rates of shared species. Moreover, root-associated samples showed higher species sharing among them.

According to Teixeira et al. [68], the presence of vascular plants in soils of Admiralty Bay plays an important role in the structure of bacterial communities. Possible explanations for this are the rhizosphere effect and the soil properties that influence more the structure of fungal communities. For example, the carbon content found in root-associated soil samples was higher than in soil samples (except for sample S4), and as the soil microbiota is composed mainly of heterotrophic microorganisms they rely on the carbon released by the roots as an energy source [67]. Another environmental factor related to the composition of the fungal communities was the temperature. There was a higher number of isolates obtained at $15^{\circ} \mathrm{C}$ than at $5{ }^{\circ} \mathrm{C}$, and the analysis of similarities showed that there was a significant difference between the communities' composition at these temperatures. Nonetheless, the test showed that the temperature itself is not a factor that fully explains the observed differences between the groups of isolates at 15 and $5{ }^{\circ} \mathrm{C}(R=0.479)$, and other factors need to be taken into account. Studying soil communities along a transect of many islands in the Antarctic Peninsula, Dennis et al. [69] verified that the fungal communities' composition was not associated with latitude, which suggested that temperature is not a key factor in the composition of fungal soil communities along the Antarctic Peninsula. Comparing our results with the results from Dennis et al., it can be inferred that temperature plays a significant role in the local level (given that the sampling points in our study are placed on the same island and around the same bay), and once one analyzes soil communities on a larger scale, this factor becomes less significant.

\section{Marine Sediment Diversity}

The $\alpha$-diversity analyses showed that sample Sed 4 was the richest one, while Sed1 was the most diverse. The triplicates from sample Sed 4 were collected at $20 \mathrm{~m}$ (average depth) and at $0.1{ }^{\circ} \mathrm{C}$ (average temperature), and triplicates from sample Sed 1 were collected at 24.7 (average depth) and $0.6{ }^{\circ} \mathrm{C}$ (average temperature). These results revealed that samples collected at $20 \mathrm{~m}$ or deeper and at temperatures near $0{ }^{\circ} \mathrm{C}$ presented higher richness and diversity than the sample collected in the intertidal zone (superficial sample).

The results from $\beta$-diversity were expected; samples Sed 4 and Sed 5 showed higher species sharing. Both were collected in the same region. However, despite the higher similarity of these samples, the sharing percentage was low, below $50 \%$. This hypothesis is sustained by the NMDS graph (where the samples were totally separated). Analyzing the distribution pattern and the isolated species, it is possible to infer that the geographic location is the main reason for the differences.
Samples Sed4 and Sed5 are distant from the others, probably because geographically their distance is higher. And the difference between Sed 4 and Sed5 is probably due to the different types of the samples and their temperatures; Sed4 is from sediment and Sed5 from the intertidal zone. By bringing together all this information, it is possible to infer that fungal diversity in all samples changes due to the collecting region. Each sample is unique, and this provides the development of distinct fungal communities.

The ANOSIM showed that there was also a significant difference between the communities' composition at 15 and $5{ }^{\circ} \mathrm{C}$. As for the soil samples, temperature itself is not a factor that fully explains the observed differences between the groups of isolates at the two temperatures $(R=0.33)$.

\section{Cold-Adapted Enzymes}

\section{Ligninolytic Enzymes}

The majority of filamentous fungi positive for lignignolytic enzymes in the first screening were isolated at $15^{\circ} \mathrm{C}$ and come from root-associated soil. The low amount of fungi capable of producing ligninolytic enzymes could be related to the restriction of lignocellulosic material in Antarctic environments. Although no laccase activity was observed for yeasts, Vishniac [70] reported that lineages of Cryptococcus isolated from Antarctica could produce laccase, among other enzymes. In a previous study from our group, with 160 filamentous fungi isolated from different Antarctic substrates (wood, sea stars, marine sediment, lichen, algae), it was verified that 29 had probable laccase activity using the same screening method as used here (data not publishd yet). As far as we know, there is no study related to the production of ligninolytic enzymes by Antarctic filamentous fungi.

\section{Lipase and Protease}

Data from lipase in solid and liquid media revealed that yeasts were more expressive in lipase production than the filamentous fungi. Among the positive yeasts, $56.2 \%$ were recovered from sample Sed5 (Refugio 2 - intertidal zone). This result can be justified by the fact that this sample came from a transition zone, where the accumulation of oil and fat (from dead animals) and pollution (oil, boat fuel) brought by tides is more likely to happen. Duarte [71] reported lipase activity from two genera isolated from Antartic samples: Cryptococcus and Leucosporidium (between 0.1 and $0.23 \mathrm{U} \mathrm{mL}^{-1}$ ). In this study, the highest activity $\left(0.88 \mathrm{U} \mathrm{mL}^{-1}\right)$ was from Metschnikowia sp. CRM 1589. Yeasts from the phylum Ascomycota, in general, are able to produce lipase, especially the ones from the genera Candida, Yarrowia, and Saccharomyces [72]. Vaca et al. [73] reported lipase activity from two isolates of $M$. australis, but only the qualitative procedure was done. 
Protease activity was more expressive in filamentous fungi than in yeasts. All positive isolates were recovered from sediment samples (Sed1, Sed2, Sed3 e, Sed4) and none from the intertidal zone (Sed5). Pseudogymnoascus sp. CRM1533 showed higher protease activity $\left(6.21 \mathrm{U} \mathrm{mL}^{-1}\right)$. The protease production ability of the Pseudogymnoascus genus has been reported in literature, but most of the studies only do the qualitative screening, and there is not much data about protease activity quantification [74-77].

In conclusion, results from the present work revealed that Pseudogymnoascus sp. and representatives of the genus Penicillium were dominant in all marine sediment samples, while Metschnikowia was the most abundant yeast genus in this Antarctic environment. Pseudogymnoascus sp. was also dominant in soil samples, as well as yeasts of the genus Leucosporidium. We showed that despite being located within the same bay, each sampling point we assessed is unique in its physical-chemical composition and fungal community. This shows the complexity of the Antarctic environment and that further studies need to be performed to fully understand the dynamics of fungal communities. Oxidative and hydrolytic enzymes were produced by fungal isolates from soils and marine sediments, respectively. Although few soil fungi presented the capacity to produce ligninolytic enzymes, many fungi were able to produce protease and lipase. The fungal collection obtained in the present study is currently being investigated in the search for plant growth promoter and anticancer compounds and for biopesticides.

Funding Information This paper was supported by grants financed by FAPESP (reference numbers: \#2013/19486-0 and \#2016/07957-7), and by scholarships financed by CAPES. LDS and AR thank the National Council for Scientific and Technological Development (CNPq) for Productivity Fellowships 304103/2013-6 and 305341/2015-4. LDS thanks MICROSFERA project (PROANTAR/CNPq) for the support with sample collection.

\section{Compliance with Ethical Standards}

Conflict of Interest The authors declare that they have no conflict of interest.

\section{References}

1. Feller G (2013) Psychrophilic enzymes: from folding to function and biotechnology. Scientifica 2013:512840-512828. https://doi. org $/ 10.1155 / 2013 / 512840$

2. Shivaji S, Prasad GS (2009) Antarctic yeasts: biodiversity and potential applications. In: Yeast biotechnology: diversity and applications. pp 3-18

3. Singh J, Dubey AK, Singh RP (2011) Antarctic terrestrial ecosystem and role of pigments in enhanced UV-B radiations. Rev Environ Sci Biotechnol 10:63-77

4. Berlemont R, Pipers D, Delsaute M, Angiono F, Feller G, Galleni M, Power P (2011) Exploring the Antarctic soil metagenome as a source of novel cold-adapted enzymes and genetic mobile elements. Rev Argent Microbiol 43:94-103. https://doi.org/10.1590/ S0325-75412011000200005

5. Pointing SB, Chan Y, Lacap DC, Lau MCY, Jurgens JA, Farrell RL (2009) Highly specialized microbial diversity in hyper-arid polar desert. Proc Natl Acad Sci 106:19964-19969. https://doi.org/10. 1073/pnas.0908274106

6. Wynn-Williams DD (1996) Antarctic microbial diversity: the basis of polar ecosystem processes. Biodivers Conserv 5:1271-1293. https://doi.org/10.1007/BF00051979

7. D'Elia T, Veerapaneni R, Theraisnathan V, Rogers S (2009) Isolation of fungi from Lake Vostok accretion ice. Mycologia 101:751-763

8. Onofri S, Selbmann L, Zucconi L, Pagano S (2004) Antarctic microfungi as models for exobiology. Planet Space Sci 52:229 237. https://doi.org/10.1016/j.pss.2003.08.019

9. Yergeau E, Kowalchuk GA (2008) Responses of Antarctic soil microbial communities and associated functions to temperature and freeze-thaw cycle frequency. Environ Microbiol 10:22232235. https://doi.org/10.1111/j.1462-2920.2008.01644.x

10. Vaz ABM, Rosa LH, Vieira MLA, Garcia V, Brandão LR, Teixeira LCRS, Moliné M, Libkind D, van Broock M, Rosa CA (2011) The diversity, extracellular enzymatic activities and photoprotective compounds of yeasts isolated in Antarctica. Braz J Microbiol 42: 937-947. https://doi.org/10.1590/S1517-83822011000300012

11. Georlette D, Blaise V, Collins T, D'Amico S, Gratia E, Hoyoux A, Marx JC, Sonan G, Feller G, Gerday C (2004) Some like it cold: biocatalysis at low temperatures. FEMS Microbiol Rev 28:25-42. https://doi.org/10.1016/j.femsre.2003.07.003

12. Siddiqui KS, Cavicchioli R (2006) Cold-adapted enzymes. Annu Rev Biochem 75:403-433. https://doi.org/10.1146/annurev. biochem.75.103004.142723

13. Maciel MJM, Castro e Silva A, Ribeiro HCT (2010) Industrial and biotechnological applications of ligninolytic enzymes of the basidiomycota: a review. Electron J Biotechnol 13:1-13. https://doi.org/ 10.2225/vol13-issue6-fulltext-2

14. Pannu JS, Kapoor RK (2014) Microbial laccases: a mini-review on their production, purification and applications. Int J Pharm Arch 3: 528-536

15. Viswanath B, Rajesh B, Janardhan A et al (2014) Fungal laccases and their applications in bioremediation. Enzyme Res. https://doi. org $/ 10.1155 / 2014 / 163242$

16. Cotârleț M, Negoiță TGH, Bahrim GE, Stougaard P (2011) Partial characterization of cold active amylases and proteases of Streptomyces sp from Antarctica. Braz J Microbiol 42:868-877. https://doi.org/10.1590/S1517-83822011000300005

17. Damaso MCT, Passianoto MA, De Freitas SC et al (2008) Utilization of agroindustrial residues for lipase production by solid-state fermentation. Braz J Microbiol 39:676-681. https:// doi.org/10.1590/S1517-83822008000400015

18. Duarte AWF, dos Santos JA, Vianna MV et al (2017) Cold-adapted enzymes produced by fungi from terrestrial and marine Antarctic environments. Crit Rev Biotechnol 38:600-619 1-20

19. Camargo O, Moniz A, Jorge J, Valadares J (2009) Métodos de Análise Química, Mineralógica e Física dos Solos do Instituto Agronômico de Campinas. In: Boletim Técnico 106. Campinas, pp 47-50

20. Mehra O, Jackson M (1960) Iron oxide removal from soils and clays by a dithionite-citrate system buffered with sodium bicarbonate. In: National Conference on Clays and Clays Minerals, 7, Washington, D.C. Pergamon Press, pp 317-327

21. McKeague JA, Day JH (1966) Dithionite- and oxalate-extractable $\mathrm{Fe}$ and $\mathrm{Al}$ as aids in differentiating various classes of soils. Can J Soil Sci 46:13-22. https://doi.org/10.4141/cjss66-003

22. McKeague JA, Brydon JE, Miles NM (1971) Differentiation of forms of extractable iron and aluminum in soils1. Soil Sci Soc 
Am J 35:33. https://doi.org/10.2136/sssaj1971. 03615995003500010016x

23. Savitha J, Srividya S, Jagat R et al (2007) Identification of potential fungal strain(s) for the production of inducible, extracellular and alkalophilic lipase. Afr J Biotechnol 6:564-568

24. Lacerda LT, Gusmão LFP, Rodrigues A (2018) Diversity of endophytic fungi in Eucalyptus microcorys assessed by complementary isolation methods. Mycol Prog 17:1-9. https://doi.org/10.1007/ s11557-018-1385-6

25. Gelfand D, Sninsky J, White T (1990) PCR protocols: a guide to methods and applications. Academic Press, New York

26. Sampaio JP, Gadanho M, Santos S et al (2001) Polyphasic taxonomy of the basidiomycetous yeast genus Rhodosporidium: Rhodosporidium kratochvilovae and related anamorphic species. Int J Syst Evol Microbiol 51:687-697. https://doi.org/10.1099/ 00207713-51-2-687

27. De Almeida JMGCF (2005) Yeast community survey in the Tagus estuary. FEMS Microbiol Ecol 53:295-303. https://doi.org/10. 1016/j.femsec.2005.01.006

28. Duarte AWF, Dayo-Owoyemi I, Nobre FS, Pagnocca FC, Chaud LCS, Pessoa A, Felipe MGA, Sette LD (2013) Taxonomic assessment and enzymes production by yeasts isolated from marine and terrestrial Antarctic samples. Extremophiles 17:1023-1035. https:// doi.org/10.1007/s00792-013-0584-y

29. Kurtzman CP, Robnett CJ (1998) Identification and phylogeny of ascomycetous yeasts from analysis of nuclear large subunit (26S) ribosomal DNA partial sequences. Antonie van Leeuwenhoek, Int J Gen Mol Microbiol 73:331-371. https://doi.org/10.1023/A: 1001761008817

30. Hall TA (1999) BioEdit: a user-friendly biological sequence alignment editor and analysis program for windows 95/98/NT. Nucleic Acids Symp Ser 41:95-98

31. Katoh K, Standley DM (2013) MAFFT multiple sequence alignment software version 7: improvements in performance and usability. Mol Biol Evol 30:772-780. https://doi.org/10.1093/molbev/ mst010

32. Kumar S, Stecher G, Tamura K (2016) MEGA7: molecular evolutionary genetics analysis version 7.0 for bigger datasets. Mol Biol Evol 33:1870-1874. https://doi.org/10.1093/molbev/msw054

33. Kimura M (1980) A simple method for estimating evolutionary rates of base substitutions through comparative studies of nucleotide sequences. J Mol Evol 16:111-120. https://doi.org/10.1007/ BF01731581

34. Hammer Ø, Harper DATAT, Ryan PD (2001) PAST: paleontological statistics software package for education and data analysis. Palaeontol Electron 4(1):1-9. https://doi.org/10.1016/j.bcp.2008. 05.025

35. Colwell RK (2013) EstimateS: Statistical estimation of species richness and shared species from samples. Version 9 and earlier. User's Guide and application. http://purl.oclc.org/estimates

36. Verma AK, Raghukumar C, Verma P, Shouche YS, Naik CG (2010) Four marine-derived fungi for bioremediation of raw textile mill effluents. Biodegradation 21:217-233. https://doi.org/10.1007/ s10532-009-9295-6

37. Kouker G, Jaeger KE (1987) Specific and sensitive plate assay for bacterial lipases. Appl Environ Microbiol 53:211-213

38. Arora DS, Gill PK (2001) Comparison of two assay procedures for lignin peroxidase. Enzym Microb Technol 28:602-605. https://doi. org/10.1016/S0141-0229(01)00302-7

39. Wariishi H, Valli K, Gold MH (1992) Manganese(II) oxidation by manganese peroxidase from the basidiomycete Phanerochaete chrysosporium: kinetic mechanism and role of chelators. J Biol Chem 267:23688-23695. https://doi.org/10.1006/abbi.1998.0602

40. Buswell JA, Cai Y, Chang S (1995) Effect of nutrient nitrogen on manganese peroxidase and lacase production by Lentinula (Lentinus) edodes. FEMS Microbiol Lett 128:81-87
41. Yang J, Koga Y, Nakano H, Yamane T (2002) Modifying the chainlength selectivity of the lipase from Burkholderia cepacia KWI-56 through in vitro combinatorial mutagenesis in the substrate-binding site. Protein Eng 15:147-152. https://doi.org/10.1093/protein/15.2. 147

42. Charney J, Tomarelli RM (1947) A colorimetric method for the determination of the proteolytic activity of duodenal juice. J Biol Chem 171:501-505

43. Costa R, Götz M, Mrotzek N et al (2006) Effects of site and plant species on rhizosphere community structure as revealed by molecular analysis of microbial guilds. FEMS Microbiol Ecol 56:236249. https://doi.org/10.1111/j.1574-6941.2005.00026.x

44. Berríos G, Cabrera G, Gidekel M, Gutiérrez-Moraga A (2013) Characterization of a novel antarctic plant growth-promoting bacterial strain and its interaction with antarctic hair grass (Deschampsia antarctica Desv). Polar Biol 36:349-362. https:// doi.org/10.1007/s00300-012-1264-6

45. Ruisi S, Barreca D, Selbmann L, Zucconi L, Onofri S (2007) Fungi in Antarctica. Rev Environ Sci Biotechnol 6:127-141. https://doi. org/10.1007/s11157-006-9107-y

46. Carrasco M, Rozas J, Barahona S, Alcaíno J, Cifuentes V, Baeza M (2012) Diversity and extracellular enzymatic activities of yeasts isolated from King George Island, the sub-Antarctic region. BMC Microbiol 12:251. https://doi.org/10.1186/1471-2180-12-251

47. Godinho VM, Furbino LE, Santiago IF, Pellizzari FM, Yokoya NS, Pupo D, Alves TMA, S Junior PA, Romanha AJ, Zani CL, Cantrell CL, Rosa CA, Rosa LH (2013) Diversity and bioprospecting of fungal communities associated with endemic and cold-adapted macroalgae in Antarctica. ISME J 7:1434-1451. https://doi.org/ 10.1038/ismej.2013.77

48. Loque CP, Medeiros AO, Pellizzari FM, Oliveira EC, Rosa CA, Rosa LH (2010) Fungal community associated with marine macroalgae from Antarctica. Polar Biol 33:641-648. https://doi. org/10.1007/S00300-009-0740-0

49. Sampaio J (2011) Leucosporidium Fell, Statzell, I. L. Hunter-Phaff (1969). In: Kurtzman CP, Fell J, Boekhout (eds) The yeasts: a taxonomic study, v. 3, part. Elsevier, Amsterdam, pp 1485-1494

50. Hayes MA (2012) The Geomyces fungi: ecology and distribution. Bioscience 62:819-823. https://doi.org/10.1525/bio.2012.62.9.7

51. Arenz BE, Held BW, Jurgens JA, Farrell RL, Blanchette RA (2006) Fungal diversity in soils and historic wood from the Ross Sea region of Antarctica. Soil Biol Biochem 38:3057-3064. https://doi.org/10. 1016/j.soilbio.2006.01.016

52. McRae CF, Seppelt RD, Hocking AD (1999) Penicillium species from terrestrial habitats in the Windmill Islands, East Antarctica, including a new species, Penicillium antarcticum. Polar Biol 21: 97-111. https://doi.org/10.1007/s003000050340

53. Crous PW, Braun U, Schubert K, Groenewald JZ (2007) Delimiting Cladosporium from morphologically similar genera. Stud Mycol 58:33-56. https://doi.org/10.3114/sim.2007.58.02

54. Cruywagen EM, Crous PW, Roux J, Slippers B, Wingfield MJ (2015) Fungi associated with black mould on baobab trees in southern Africa. Antonie van Leeuwenhoek, Int J Gen Mol Microbiol 108:85-95. https://doi.org/10.1007/s10482-015-0466-7

55. Piñar G, Sterflinger K, Pinzari F (2015) Unmasking the measleslike parchment discoloration: molecular and microanalytical approach. Environ Microbiol 17:427-443. https://doi.org/10.1111/ $1462-2920.12471$

56. Sandoval-Denis M, Sutton DA, Martin-Vicente A, Cano-Lira JF, Wiederhold N, Guarro J, Gené J (2015) Cladosporium species recovered from clinical samples in the United States. J Clin Microbiol 53:2990-3000. https://doi.org/10.1128/JCM.01482-15

57. Zhang E, Tanaka T, Tajima M, Tsuboi R, Nishikawa A, Sugita T (2011) Characterization of the skin fungal microbiota in patients with atopic dermatitis and in healthy subjects. Microbiol Immunol 55:625-632. https://doi.org/10.1111/j.1348-0421.2011.00364.x 
58. Rossman AY, Allen WC, Castlebury LA (2016) New combinations of plant-associated fungi resulting from the change to one name for fungi. IMA Fungus 7:1-7. https://doi.org/10.5598/imafungus.2016. 07.01.01

59. Bonugli-Santos R, Passarini C, Rodrigues M et al (2009) Avaliação do potencial biosurfactante de fungos filamentosos associados a cnidários marinhos com atividade de degradação de HPAs. Microbiol Foco 7:12-16

60. Budziszewska J, Szypula W, Wilk M, Wrzosek M (2011) Paraconiothyrium babiogorense sp nov., a new endophyte from fir club moss Huperzia selago (Huperziaceae). Mycotaxon 115: 457-468. https://doi.org/10.5248/115.457

61. Crous PW, Wingfield MJ, Guarro J, Cheewangkoon R, van der Bank M, Swart WJ, Stchigel AM, Cano-Lira JF, Roux J, Madrid H, Damm U, Wood AR, Shuttleworth LA, Hodges CS, Munster M, de Jesús Yáñez-Morales M, Zúñiga-Estrada L, Cruywagen EM, de Hoog GS, Silvera C, Najafzadeh J, Davison EM, Davison PJN, Barrett MD, Barrett RL, Manamgoda DS, Minnis AM, Kleczewski NM, Flory SL, Castlebury LA, Clay K, Hyde KD, Maússe-Sitoe SND, Chen S, Lechat C, Hairaud M, LesageMeessen L, Pawłowska J, Wilk M, Śliwińska-Wyrzychowska A, Mętrak M, Wrzosek M, Pavlic-Zupanc D, Maleme HM, Slippers B, Mac Cormack WP, Archuby DI, Grünwald NJ, Tellería MT, Dueñas M, Martín MP, Marincowitz S, de Beer ZW, Perez CA, Gené J, Marin-Felix Y, Groenewald JZ (2013) Fungal planet description sheets: 154 - 213. Persoonia 31:188-296. https://doi.org/ 10.3767/003158513X675925

62. Gomes NGM, Lefranc F, Kijjoa A, Kiss R (2015) Can some marine-derived fungal metabolites become actual anticancer agents? Mar Drugs 13:3950-3991. https://doi.org/10.3390/ md13063950

63. Verkley GJM, Da Silva M, Wicklow DT, Crous PW (2004) Paraconiothyrium, a new genus to accommodate the mycoparasite Coniothyrium minitans, anamorphs of Paraphaeosphaeria, and four new species. Stud Mycol 50:323-335

64. Upson R, Newsham KK, Bridge PD, Pearce DA, Read DJ (2009) Taxonomic affinities of dark septate root endophytes of Colobanthus quitensis and Deschampsia antarctica, the two native Antarctic vascular plant species. Fungal Ecol 2:184-196. https:// doi.org/10.1016/j.funeco.2009.02.004

65. Gonçalves VN, Carvalho CR, Johann S, Mendes G, Alves TMA, Zani CL, Junior PAS, Murta SMF, Romanha AJ, Cantrell CL, Rosa CA, Rosa LH (2015) Antibacterial, antifungal and antiprotozoal activities of fungal communities present in different substrates from Antarctica. Polar Biol 38:1143-1152. https://doi.org/10.1007/ s00300-015-1672-5

66. Haichar FEZ, Marol C, Berge O et al (2008) Plant host habitat and root exudates shape soil bacterial community structure. ISME J 2: 1221-1230. https://doi.org/10.1038/ismej.2008.80
67. Hartmann A, Schmid M, van Tuinen D, Berg G (2009) Plant-driven selection of microbes. Plant Soil 321:235-257. https://doi.org/10. 1007/s11104-008-9814-y

68. Teixeira LCRS, Yeargeau E, Balieiro FC et al (2013) Plant and bird presence strongly influences the microbial communities in soils of Admiralty Bay, Maritime Antarctica. PLoS One 8:e66109. https:// doi.org/10.1371/journal.pone.0066109

69. Dennis PG, Rushton SP, Newsham KK, Lauducina VA, Ord VJ, Daniell TJ, O'Donnell AG, Hopkins DW (2012) Soil fungal community composition does not alter along a latitudinal gradient through the maritime and sub-Antarctic. Fungal Ecol 5:403-408. https://doi.org/10.1016/j.funeco.2011.12.002

70. Vishniac HS (1996) Biodiversity of yeasts and filamentous microfungi in terrestrial Antarctic ecosystems. Biodivers Conserv 5:1365-1378. https://doi.org/10.1007/BF00051983

71. Duarte AWF (2014) Biodiversidade de leveduras derivadas de ecossistemas Antárticos marinhos e terrestres e prospecção de lipases. Universidade de São Paulo

72. Vakhlu J, Kour A (2006) Yeast lipases: enzyme purification, biochemical properties and gene cloning. Electron J Biotechnol 9:6985

73. Vaca I, Faúndez C, Maza F, Paillavil B, Hernández V, Acosta F, Levicán G, Martínez C, Chávez R (2013) Cultivable psychrotolerant yeasts associated with Antarctic marine sponges. World J Microbiol Biotechnol 29:183-189. https://doi.org/10. 1007/s11274-012-1159-2

74. Chaturvedi V, Springer DJ, Behr MJ, Ramani R, Li X, Peck MK, Ren P, Bopp DJ, Wood B, Samsonoff WA, Butchkoski CM, Hicks AC, Stone WB, Rudd RJ, Chaturvedi S (2010) Morphological and molecular characterizations of psychrophilic fungus Geomyces destructans from New York bats with white nose syndrome (WNS). PLoS One 5:e10783. https://doi.org/10.1371/journal. pone. 0010783

75. Edgington S, Thompson E, Moore D, Hughes KA, Bridge P (2014) Investigating the insecticidal potential of Geomyces (Myxotrichaceae: Helotiales) and Mortierella (Mortierellacea: Mortierellales) isolated from Antarctica. Springerplus 3:289. https://doi.org/10.1186/2193-1801-3-289

76. Krishnan A, Alias SA, Wong CMVL, Pang KL, Convey P (2011) Extracellular hydrolase enzyme production by soil fungi from King George Island, Antarctica. Polar Biol 34:1535-1542. https://doi. org/10.1007/s00300-011-1012-3

77. Santos W, Nascimento T, Maciel A, et al (2015) A rapid screening of significative variables in the production of proteases and amylases by submerged fermentation of Geomyces pannorum S2B. In: Anais do XXVIII Congresso Brasileiro de Microbiologia. Florianópolis 